\title{
Fluencia de tableros MDF sometidos a carga constante y condiciones cíclicas de humedad relativa. Influencia del revestimiento de superficies
}

\author{
Creep of MDF panels under constant load and cyclic \\ environmental conditions. Influence of surface coating
}

Dr. JUAN IGNACIO FERNÁNDEZ-GOLFÍN SECO; Dr. M. RAFAEL DÍEZ BARRA

Fecha de recopción: 11-II-97

CIFOR-INIA (Área de Industrias Forestales)

Fecha de aceptación: 26-III-97

ESPAÑA

\section{RESUMEN}

(uatro tipos de acabados superficiales distintos, aplicados sobre tableros MIDli comerciales de $19 \mathrm{~mm}$ de espesor, son empleados en el estudio del comportamiento reológico de los tableros MIDF ante condiciones alternantes de humedad relativa $\left(20^{\circ} \mathrm{C} / 30 \% \mathrm{hr}-20^{\circ} \mathrm{C} 90 \% \mathrm{hr}\right)$.

Para el anális del comportamiento reológico de los tahleros se consideran tres niveles de tensión distintos (20) \%, $30 \%$. 40)\%), calculados en función de la carga uiltima de rotura a flexión. Los ensayos son efectuados aplicando la carga en punto medio.

La fluencia relativa de los tableros $M$ HI) I resulta ser superior a la exhibida por los tableros de particulas de similiares caracteristicas, observándose que los revestimientos melaminicos aplicados superficialmente influyen eficazmente en la mejora de su comportamiento reológico.

('uando la comparación entre tableros MI) $\mathrm{Y}$ y de particulas se efectúa considerando idénticos niveles de carga aplicada en vez de tensión, el resultado de la comparación resulta ser, justamente, el contrario.

\section{SUMMARY}

lour different strategies of surface coating (based on $810 \mathrm{~g} \mathrm{~m}^{2}$ melamin impregnated papers) were used on $19 \mathrm{~mm}$ thick commercial .MIJH panels to assess its reological hehaviour under cyclic humidity conditions (20 " $\left.{ }^{\circ} \mathrm{C} 30 \% \mathrm{rh}-20^{\circ} \mathrm{C}^{\circ} 90 \% \mathrm{orh}\right)$.

Three different levels of stress (20) \%, $30 \%$ and $f(1) \%)$, based on the ultimate load in hending, were used. Tests were conducted by' means of the three points load system.

For the same stress level, the relative creep of .MII li panels was higher than that in particle boards with similar characteristics. This behaviour was just the opposit" than the one exhibited by the panels when the comparison is made based on the same level of load (kg)

Melamin coating seems to strongly influence the creep hehaviour of the raw material, especially when surface and edge coating were combined.

\section{INTRODUCCIÓN}

Debe entenderse por tableros MDF (Medium Density Fiberboards) a tableros obtenidos por el encolado, bajo presión, de fibras de madera con resinas

\section{INTRODUCTION}

It must be understood by MII)F (1/edium I)ensity Fiberboards) to boards obtained gluing wood fibers by thermosetting resins (mainly lif or 
termoendurecibles (normalmente de Urea-formaldehido o con pequeña adiciones de Melamina-formaldehido). La densidad de estos tableros oscila en el entorno de los $700 \mathrm{~kg} / \mathrm{m}^{3}$.

Actualmente existe una cierta controversia en el seno del Comité Europeo de Normalización encargado de la normalización de los tableros de madera, CEN TC 112 , sobre si es permisible o no emplear a los tableros MDF en funciones portantes o altamente portantes en las condiciones de servicio 2 del Eurocodigo 5. Como referencia, debe indicarse que tal posibilidad está permitida al tablero de partículas, con lo que tiene las puertas abiertas para su empleo en aplicaciones claramente constructivas, como base de cubiertas o cerramientos exteriores.

La principal razón que exhiben los contrarios a que el tablero MDF pueda trabajar en dichas condiciones es su comportamiento reológico, que es considerado como peor que el del tablero de partículas. No obstante, esta afirmación está sujeta a gran debate en la actualidad.

El presente trabajo trata de comparar el comportamiento de ambos tableros en condiciones próximas a las de servicio 2 y de extraer conclusiones sobre la posibilidad de su uso en funciones portantes en la construcción.

Un notable esfuerzo ha sido realizado en el estudio empírico y posterior modelización del comportamiento reológico de la madera (1) y de los tableros de madera (2), especialmente de partículas (3). Sin embargo, pocos trabajos (4) han sido publicados hasta el momento sobre el comportamiento reológico de los tableros MDF y menos, aún, sobre la influencia que en este comportamiento puede tener el recubrimiento superficial (5) y (6).

Dinwoodie y Bonfield (2) afirman que el tablero MDF presenta una mayor propensión hacia la fluencia conforme la humedad relativa aumenta. Esta propensión resulta ser mayor que en tableros de partículas. Boehme (4) comprobó sobre tableros comerciales MDF de $19 \mathrm{~mm}$ de espesor y trabajando en condiciones cíclicas semanales de $20^{\circ} \mathrm{C} / 30 \%-20^{\circ} \mathrm{C} / 85 \%$ una clara mayor tendencia a la fluencia, medida en términos de fluencia relativa, que en tableros de partículas.

Fernández-Golfin y Díez Barra (5) estudiaron la influencia de un revestimiento tradicional $\left(80 \mathrm{~g} / \mathrm{m}^{2}\right)$ de tipo melamínico sobre el comportamiento reológico del tablero de partículas de UF, concluyendo que la aplicación de revestimientos de este tipo reducia la fluencia relativa y aumentaba el tiempo hasta la rotura. Similares conclusiones obtuvo Bach et al., en 1993 (6), aplicando productos repelentes al agua.
MUF) under pressure. The density of such a boards is about $700 \mathrm{~kg} / \mathrm{m}^{3}$.

Currently it exists a certain controversy in the European Committee for Normalization in charge with the standardization of the wood based panels, CEN/TC 112, on whether it is permissible or not to employ the MDF boards in loadbearing uses in the class of service 2 of the Eurocode 5. As reference must be indicated that such possibility is permitted for the particleboards, being then possible its use in applications clearly constructive, as in roofs structures, walls, etc.

The main reason argued for the groups opposed to the possiblity of permitting such a uses to the MII panels is its rheological hehaviour in that environmental condition. that it i. considered as worse than that of particleboards. Vevertheless this affirmation is held to great discussion at present.

The present work tries to comparing the behaviour of both types of boards in closed conditions to those of class service 2 and of extracting conclusions of the possibility of its use in loadbearing functions.

Votable effort has been made in the empirical study and subsequent modelling of the rheological behaviour of timber (1) and wood based panels (2), especially in particleboards (3). Nevertheless, few' studies (7) have been published to date on the rheological behaviour of $\mathrm{MII}) \mathrm{F}$ boards and even fewer on the influence that superficial coatings can have on this behaviour (5) and (0).

Dinwoodie and Bonfield (2) reported that WII boards show greater propensity to creep as humidity rises. This propensity is greater in $M I I) H$ panels than in particleboards. Boehme (4) reported on $19 \mathrm{~mm}$ thick commercial MI)F boards, working in weekly cyclic conditions of $20^{\circ} \mathrm{C} / 30 \%-20^{\circ} \mathrm{C} / 85 \%$ a greater tendency to creep, measured in terms of relative creep, than in particleboards.

Fernandez-(iolfin and Diez Barra (5) studied the influence of the traditional melamin overlay $\left(80 \mathrm{~g} / \mathrm{m}^{2}\right)$ on the rheological behaviour of UF particleboards, concluding that the application of this type of overlay reduced relative creep and increased time to failure. Similar conclusions were drawn by Bach et al.; in 1993 (6), applying water repellent products. 
El empleo habitual de condiciones alternantes de humedad relativa (30\%-90\%) en trabajos de esta naturaleza sobre tableros, surge de la comprobación, en numerosos estudios, sobre todo en tableros de partículas (7-20), que, bajo estas condiciones, la fluencia es varias veces superior que en condiciones constantes, a $20{ }^{\circ} \mathrm{C} / 65 \%$ y significativamente superior que en condiciones sostenidas de $20 \% 90 \%$. Esta afirmación está sometida a controversia, ya que de algunos resultados parece deducirse la conclusión contraria, si bien no todos los estudios efectuados sobre el tema son siempre estrictamente comparables (2).

Por otra parte, Dinwoodie et al. (19) demostraron que las condiciones exteriores protegidas afectan a la fluencia relativa de los tableros de partículas de una forma muy similar que las estáticas a $20^{\circ} \mathrm{C} / 90 \%$. Pese a su menor rudeza, es de destacar el creciente interés sobre estas condiciones, al corresponder con la clase 2 del Eurocodigo 5.

La realización del ensayo, bajo condiciones no estables de humedad relativa, permite introducir en el estudio del comportamiento reológico de los materiales la variable de su diferente comportamiento a la sorción (ganancia o pérdida de humedad por intercambio con el medio).

Respecto de las condiciones cíclicas de temperatura, Dinwoodie (20) demostró la mayor sensibilidad de los tableros de madera ante las condiciones alternantes de humedad que de temperatura, si bien ha quedado demostrado también el incremento que producen en la deformación las condiciones cíclicas de temperatura.

Cuando se comenzó el presente trabajo sobre tableros MDF (1992), no se encontró evidencia bibliográfica alguna que permitiera hacer pensar que las condiciones alternantes de humedad relativa no produjeran en el comportamiento reológico de estos tableros un efecto similar que en tableros de partículas, demostrándose, posteriormente, que no era del todo cierto.

Cualitativamente, el comportamiento reológico general es similar en la madera que en el tablero, pero ambos materiales difieren en su respuesta ante los fenómenos de sorción (ganancia de humedad) y de desorción (pérdida de humedad). La principal diferencia estriba en que en la madera, la deformación durante la desorción aumenta, mientras que en el tablero disminuye ligeramente, dándose el fenómeno contrario en la sorción, si bien la flecha total, al final de un ciclo completo sorción/desorción, aumenta (21).

Este proceso de alternancias de flecha, inducido por condiciones cíclicas, tanto de humedad como de
Under alternating humidity conditions (30\%-90\%), especially when working with particleboards (7-20). creep seems to be several times higher than under constant conditions at $20^{\circ} \mathrm{C} / 65 \%$ rh and considerably higher than in sustained conditions at $20^{\circ} \mathrm{C} / 90 \% \mathrm{rh}$. Even though this conclusion is arguable as some results seem to reflect the opposite, probably due to the fact that the studies have been carried out under conditions not strictly comparable (2), alternating humidity conditions have been commonly used in this kind of studies on the characterization of the rheological behaviour of wood based panels.

On the other hand, Dinwoodie et al.(19) demonstrated that protected exterior conditions affect the relative creep of particleboards in a way very similar to that of steady conditions at $20^{\circ} \mathrm{C} / 90 \%$. It is worth pointing out that a growing interest exists regarding these conditions: as they correspond to class 2 of Eurocode 5.

The experiments on the rheological characterization of wood-based panels used to consider non-steady humidity conditions, to permit the introduction and analysis of the influence of the different sorption behaviour of the panels.

Regarding cyclic temperature conditions, Dinwoodie (20) demonstrated that a board is more sensitive to alternating moisture than to changing temperatures. although it is also true that deformation increases under cyclic temperatures:

When the present study on MIDF boards began (1992), it was impossible to find any written evidence to conclude that alternating relative moisture conditions could induce on MDF boards a rheological behaviour pattern any different to that of particleboards, although at the end of this study this was one of the main conclusions.

lirom a general and qualitative viewpoint, the rheological behaviour is similar in solid wood and in wood-based panels but, these materials differ in their respective reactions to sorption and desorption. The main difference is due to the fact that, in solid wood deformation increases during desorption, while in panels deformation decreases under these conditions, although at the end of a complete sorption/desorption cycle. overall deformation increases (2I).

In solid wood this phenomenon of alternation of deformation due to both moisture and temperature 
temperatura, parece amortiguarse en la madera con el tiempo hasta el punto de que al año resulta imperceptible (22). Este fenónemo de amortiguación fue tambien constatado por Fernández-Golfín y Díez Barra (1992) (21) en tableros de partículas UF y MUF, a partir de la semana 18 y para niveles de tensión del $20 \%$ y $30 \%$.

La alternancia de flechas en tableros MDF, más acusada y temprana que en tableros de partículas, ha sido puesta de manifiesto por Boehme (4), si bien este trabajo no aporta datos sobre el final del proceso de alternancia, al detener las condiciones cíclicas en la semana 23. Por ello, nada se puede concluir de este estudio sobre el momento, a partir del cual, tiene lugar la aparición del fenómeno de amortiguación de la deformación ante los cambios de humedad del medio.

Aun cuando el tipo de cola es una variable habitual en los estudios reológicos sobre tableros de partículas (2), no ha sido empleada en el presente trabajo con MDF, ya que la presencia en el mercado español de tableros MDF con otro tipo de cola, distinto al de UF, es prácticamente nula.

\section{MATERIAL Y MÉTODOS}

Se utilizaron tableros comerciales MDF de $19 \mathrm{~mm}$, desnudos (D) y recubiertos superficialmente con melamina de $80 \mathrm{~g} / \mathrm{m}^{2}(\mathrm{M})$. El tablero recubierto (M) se preparó por recubrimiento en fábrica de los tableros desnudos (D)

Para comprobar la influencia que la limitación en el intercambio de humedad por los cantos pueda tener en el comportamiento reológico del material, parte de las probetas de ensayo de los tableros D y M fueron, a su vez, canteadas mediante la aplicación de colas de contacto y de perfiles industriales de tipo plástico, obteniéndose otros dos tipos diferentes de material de ensayo, denominados $\mathrm{C}$ (por canteado del tablero $\mathrm{D}$ ) y $B$ (por canteado del tablero $M$ ). El resumen y características de los materiales de ensayo figura en la TABLA 1

La TABLA 2 recoge un resumen de las propiedades iniciales de los tableros D y M, obtenidas de acuerdo con los procedimientos y tamaños de probetas descritos por las normas UNE correspondientes.

El sistema de aplicación de carga y la metodología general del proceso son los mismos que los empleados en el trabajo previo (21) sobre tableros de partículas permitiendo, de esta manera, la comparación de los resultados obtenidos con ambos tipos de tableros. cycling, seems to diminish with time to such a degree that after a year it is almost imperceptible (22). The same behaviour process also became apparent after the 18th week, in UF and MUF particle boards at stress levels of $20 \%$ and $30 \%$, Fernandez-Golfin and Diez Barra (1992) (21).

In MDF boards this phenomenon of alternation of deformation under cycling humidity conditions has been reported by Boehme (4), although this study does not provide information on the moment in which the process began to diminish as the cyclic conditions only continued until week 23. Therefore, this study does not permit any conclusion to be drawn regarding the similarity between $\mathrm{MDF}$ and particleboard as regards this phenomenon.

Even though the kind of adhesive is a common variable in the studies on the rheological characterization of particleboards (2), it has not been used in this study on MID as, at least in Spain, the resin used in MIJF panels is almost always $U F$.

\section{MATERIAL AND METHODS}

('ommercial $19 \mathrm{~mm}$ thick. $\mathrm{MI}$ )F boards were used, raw (I)) and overlaid with melamin resin-impregnated $80 \mathrm{~g} \mathrm{~m}^{2}$ paper (1). The surfaced overlaid boards (M) were factory prepared using the raw boards (I)) as substrate.

In order to test the effect on the rheological behaviour of the panels caused by the limitation of the exchange of moisture through the edges, part of the D and M test samples were edge sealed by means of commercial flexible and adhesive-bonded (solvent-based) polvester edge banding material. therefore creating two different test samples; $(\mathrm{C}$ (edge-sealing the raw boards, I)) and $B$ (edge-sealing the surface overlaid boards, 1). The summary and characteristics of the test samples used can be found in TABLE 1 .

TABLE 2 describes the initial properties of the I) and $1 /$ boards, obtained according to (NE (Spanish) standards regarding the testing methods and size of samples.

The system of loading and the general methodology of the process were the same as those used in the previous study (21) on particleboards, therefore permitting the comparision of the results obtained from hoth types of boards. 
TABLA 1 (TABLE I)

Características del material de ensayo

(Characteristics of the testing material)

\begin{tabular}{|c|c|c|}
\hline TABLERO (BOARD) & $\begin{array}{c}\text { RECUBRIMIENTO SUPERFICIAL } \\
\text { (SURFACE OVERLAID) }\end{array}$ & $\begin{array}{c}\text { RECUBRIMIENTO DE CANTOS } \\
\text { (EDGE FINISHED) }\end{array}$ \\
\hline D & NO & NO \\
\hline C & NO & NES) \\
\hline M & Si (YES) & Sí (YES) \\
\hline B & Si (YES) & (Y) \\
\hline
\end{tabular}

TABI $\wedge 2$ (TABLE 2)

Propiedades iniciales de los tableros (Initial properties of boards)

\begin{tabular}{|c|c|c|c|c|}
\hline $\begin{array}{c}\text { PROPIEDAD } \\
\text { (PROPERTY) }\end{array}$ & $\begin{array}{c}\text { TAMAÑO } \\
\text { PROBETA } \\
\text { (SAMPLE SIZE) } \\
\text { (mm) }\end{array}$ & $\begin{array}{c}\text { NORMA ENSAYO } \\
\text { (STANDARD) }\end{array}$ & \multicolumn{2}{|c|}{$\begin{array}{c}\text { TABLERO } \\
\text { (BOARD) }\end{array}$} \\
\hline $\begin{array}{c}\text { Peso especifico } \\
\text { (Density) } \\
\left(\mathrm{kg} / \mathrm{m}^{3}\right)\end{array}$ & $100 \times 100 \times 19$ & UNE 56.709 & 718 & 718 \\
\hline $\begin{array}{c}\text { Humedad } \\
\text { (Moisture) } \\
(\%)\end{array}$ & $50 \times 50 \times 19$ & UNE 56.710 & 7,8 & 8,0 \\
\hline MOR (kg/cm $\left.{ }^{2}\right)$ & $525 \times 50 \times 19$ & UNE 56.711 & 347 & 283 \\
\hline MOE (kg/cm $\left.{ }^{2}\right)$ & $525 \times 50 \times 19$ & UNE 56.711 & 30,300 & 36,300 \\
\hline RTP (IB) $\left(\mathrm{kg} / \mathrm{cm}^{2}\right)^{*}$ & $50 \times 50 \times 19$ & UNE 56.712 & 7,2 & 6,3 \\
\hline
\end{tabular}

* Resistencia a la tracción perpendicular (Internal bonding)

ТАВI $А ~ 3$ (TABLE 3)

Pesos aplicados $(\mathrm{kg})$, según niveles de tensión y tipo de tableros (Weight applied (kg), according to stress levels and type of board)

\begin{tabular}{||c|c|c|c|c||}
\hline \multirow{2}{*}{$\begin{array}{c}\text { NIVEL DE } \\
\text { TENSIÓN } \\
\text { (STRESS LEVEL) }\end{array}$} & D TIPO DE TABLERO (BOARD CODE) \\
\cline { 2 - 5 } & & $\mathrm{C}$ & $\mathrm{M}$ & $\mathrm{B}$ \\
\hline & & & & \\
$40 \%$ & 35,2 & 35,2 & 28,8 & 28,8 \\
$30 \%$ & 26,4 & $-\cdots$ & 21,6 & $\cdots$ \\
$20 \%$ & 17,6 & $-\cdots$ & 14,4 &.-- \\
\hline
\end{tabular}

Para cada tipo de tablero (D, C, M y B) y nivel de tensión' aplicado (ver TABLA 3), se ensayaron 4 probetas de $525 \times 50 \times 19 \mathrm{~mm}$, idénticas a las utilizadas para el ensayo previo a flexión, estudiándose tanto la evolución de la flecha como el tiempo hasta la rotura del material.

\footnotetext{
${ }^{1}$ Se cntiende por nivel detensión el cociente, expresado en \%, entre la carga aplicada y la carga máxima que el tablero es capaz de resistir. determinada en los ensayos iniciales.
}

For each board type (I), C, $M$ and B) and stress level (see TABLE 3), four samples of $525 \times 50 \times 19 \mathrm{~mm}$ were used. identical to those used in the previous bending test. Deflection under three point bending was measured for up to 42 weeks (at $20 \%$ of stress level) and the time to failure was recorded.

${ }^{\prime}$ It is understoodby stress level the quocient, expressed in \%, hetween the applied load and the maximum load that the board cam bear, determined in the initial tests 
Los ensayos sobre el material marcado como C y B, al nivel único de tensión del $40 \%$, tenían como misión conocer la influencia que la limitación del proceso de intercambio de humedad por los cantos introduce en el proceso de la fluencia.

Niveles de tensión superiores (50\% y $60 \%$ ) fueron considerados únicamente para la modelización del tiempo hasta la rotura.

Durante la primera semana de medidas, la cámara fue mantenida a $20^{\circ} \mathrm{C} / 65 \%$, pasando, a partir de este momento, a un programa cíclico $20^{\circ} \mathrm{C} / 30 \%-20{ }^{\circ} \mathrm{C} / 90 \%$, empezando por la condición seca (30\%). Los cambios de humedad se efectuaron después de cada medición semanal.

La revisión del estado físico de las probetas (tiempo hasta la rotura) se efectuó dos veces al día durante las dos primeras semanas, diariamente hasta la $6^{\mathrm{a}}$, dos veces a la semana hasta la semana $27^{a}$ y semanalmente a partir de ese momento.

Paralelamente al proceso de medición semanal de la flecha y sobre probetas idénticas a las de ensayo

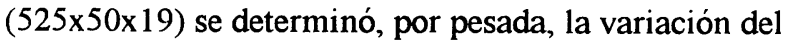
contenido de humedad.

\section{RESULTADOS Y DISCUSIÓN}

\subsection{Estudio de las deformaciones}

La TABLA 4 recoge un resumen de las flechas absolutas y relativas (en paréntesis) ${ }^{2}$ para los niveles de
The stress levels of $20 \%$ and $30 \%$ were used to record the deformation with time in boards $C$ and $B$, while the level of $40 \%$ was used to assess the influence that the limitation of the exchange of humidity through the edges has on the creep process.

Higher stress levels (50\% and $60 \%$ were also considered in the study in order to measure and modelize time to failure, but the results are not include in this paper.

During the first week, the chamber was maintained at $20^{\circ} \mathrm{C} / 65 \%$ at the end of which this became a cyclic programme $20^{\circ} \mathrm{C} / 30 \%-20^{\circ} \mathrm{C} / 90 \%$, beginning from its dry state $(30 \%)$. The humidity changes were carried out once the weekly measuring of deformation and moisture content had taken place. The moisture content was measured on matched samples to those used in the creep experiments but without load.

The revision of the samples physical state (time to failure) was carried out twice a day during the first two weeks, daily until the 6th week, twice a week until the 27th week and weekly from then on.

Simultaneously to the weekly deformation measuring process, the variations of moisture content were determined by weighing samples identical to those tested (525x50x19).

\section{RESULTS AND DISCUSSION}

\section{Creep deflection}

A summary of the results, in terms of absolute and relative (in brackets) ${ }^{2}$ creep, for stress levels of 20 and

TABLA 4 (TABLE 4)

Resumen de resultados de evolución de flecha absoluta (mm) y relativa (en paréntesis), para ambos tipos de tableros (Absolute ( $\mathrm{mm}$ ) and relative (in brackets) deformation for four types of boards))

\begin{tabular}{|c|c|c|c|c|c|c|c|c|}
\hline \multirow{4}{*}{$\begin{array}{c}\text { TIEMPO } \\
\text { (TIME) } \\
\text { (min) }\end{array}$} & \multicolumn{4}{|c|}{ PARTICULAS (PARTICLEBOARDI) } & \multicolumn{4}{|c|}{ MDF } \\
\hline & \multicolumn{2}{|c|}{ Desnudo (RAW) } & \multicolumn{2}{|c|}{ Molamina (Melamin) } & \multicolumn{2}{|c|}{ Desnudo $(R A W)(D)$} & \multicolumn{2}{|c|}{ Molamina (Melamin) (M) } \\
\hline & \multicolumn{4}{|c|}{ Solicitación (Stress levels (in \%) (Load in kgll) } & \multicolumn{4}{|c|}{ Solicitación (Stress lovels (Load)) } \\
\hline & $\begin{array}{c}20 \% \\
(8)\end{array}$ & $\begin{array}{l}30 \% \\
(12)\end{array}$ & $\begin{array}{l}20 \% \\
(8,5)\end{array}$ & $\begin{array}{c}30 \% \\
(12,8)\end{array}$ & $\begin{array}{c}20 \% \\
(17,6)\end{array}$ & $\begin{array}{c}30 \% \\
(26,4)\end{array}$ & $\begin{array}{c}20 \% \\
\{14,4\}\end{array}$ & $\begin{array}{c}30 \% \\
(21,6)\end{array}$ \\
\hline 50.400 & $\begin{array}{l}21,36 \\
(1,8)\end{array}$ & $\begin{array}{l}27,16 \\
(2,16)\end{array}$ & $\begin{array}{l}11,55 \\
(0,44)\end{array}$ & $\begin{array}{l}14,35 \\
(0,6)\end{array}$ & $\begin{array}{l}20,32 \\
(1,09)\end{array}$ & $\begin{array}{l}35,41 \\
(1,86)\end{array}$ & $\begin{array}{l}15,32 \\
(0,77)\end{array}$ & $\begin{array}{l}22,06 \\
(1,11)\end{array}$ \\
\hline 151.200 & $\begin{array}{l}23,85 \\
(2,13)\end{array}$ & $\begin{array}{l}31,19 \\
(2,63)\end{array}$ & $\begin{array}{l}12,22 \\
(0,52)\end{array}$ & $\begin{array}{l}15,60 \\
(0,74)\end{array}$ & $\begin{array}{l}31,01 \\
(2,20)\end{array}$ & $\begin{array}{l}77,53 \\
(5,26)\end{array}$ & $\begin{array}{l}19,82 \\
(1,29)\end{array}$ & $\begin{array}{l}31,14 \\
(1,98)\end{array}$ \\
\hline 201.600 & $\begin{array}{l}28,21 \\
(2,70)\end{array}$ & $\begin{array}{l}38.07 \\
(3.43)\end{array}$ & $\begin{array}{l}12.88 \\
(0.61)\end{array}$ & $\begin{array}{l}17,08 \\
(0,91)\end{array}$ & $\begin{array}{l}33,88 \\
(2,49)\end{array}$ & - & $\begin{array}{l}20,74 \\
(1,4)\end{array}$ & $\begin{array}{l}33,83 \\
(2,24)\end{array}$ \\
\hline 262.080 & $\begin{array}{l}32,54 \\
(3,26)\end{array}$ & $\begin{array}{l}46,98 \\
(4,46)\end{array}$ & $\begin{array}{l}13,92 \\
(0,74)\end{array}$ & $\begin{array}{l}19,18 \\
(1,03)\end{array}$ & $\begin{array}{l}39,76 \\
(3,10)\end{array}$ & - & $\begin{array}{l}22,27 \\
(1,57)\end{array}$ & $\begin{array}{l}37,33 \\
(2,58)\end{array}$ \\
\hline $\begin{array}{l}\text { Rotura } \\
\text { (Failure) }\end{array}$ & No & 267.040 & No & 345.600 & No & 167.880 & No & 1.068 .480 \\
\hline
\end{tabular}

\footnotetext{
${ }^{2}$ Se entiende por flecha relativa of fluencia relativa al incremento unitario de la flecha con respecto a la elástica inicial. Esta última se considera que es la flecha a los $30 \mathrm{~s}\left(\mathrm{~d}_{\mathrm{o}}\right)$. La expresión de cálculo será, pues: $\left(\mathrm{d}_{\mathrm{t}}-\mathrm{d}_{\mathrm{o}}\right) / \mathrm{d}_{\mathrm{o}}$.
} 2 Relative deformation is considered as the relative increment of the
deformation as regards the initial elastic deformation: $\left(d_{-}-d_{d}\right) / d_{o}$ 
tensión del 20 y $30 \%$ y los tableros D y M, así como, con fines comparativos, un resumen de los resultados de un estudio anterior (21) con tablero de partículas.

Las Figuras la y $1 \mathrm{~b}$ recogen, para los cuatro tipos de tableros y de forma gráfica, la evolución de la flecha absoluta con el tiempo.

Del análisis de las Figuras la y lb y de los datos de la TABLA 4, se pone de manifiesto que el recubrimiento de las caras (tablero $\mathrm{M}$ ) y cantos (tablero B) transforma
$30 \%$ on $D$ and $M$ boards is included in TABLE 4. This TABLE also includes a summary of the results of a previous study on particleboards (21) in order to make a comparision of creep behaviour among the different board types.

Figures $1 a$ and $1 b$ reflect the evolution of absolute deformation $(\mathrm{mm})$ with time for the four types of boards.

From the analisys of Figures $1 a$ and $1 b$ along with the data in TABLE 4 it becomes apparent that melamin coatings on surfaces (board $M$ ) and on surfaces and edges (board B)
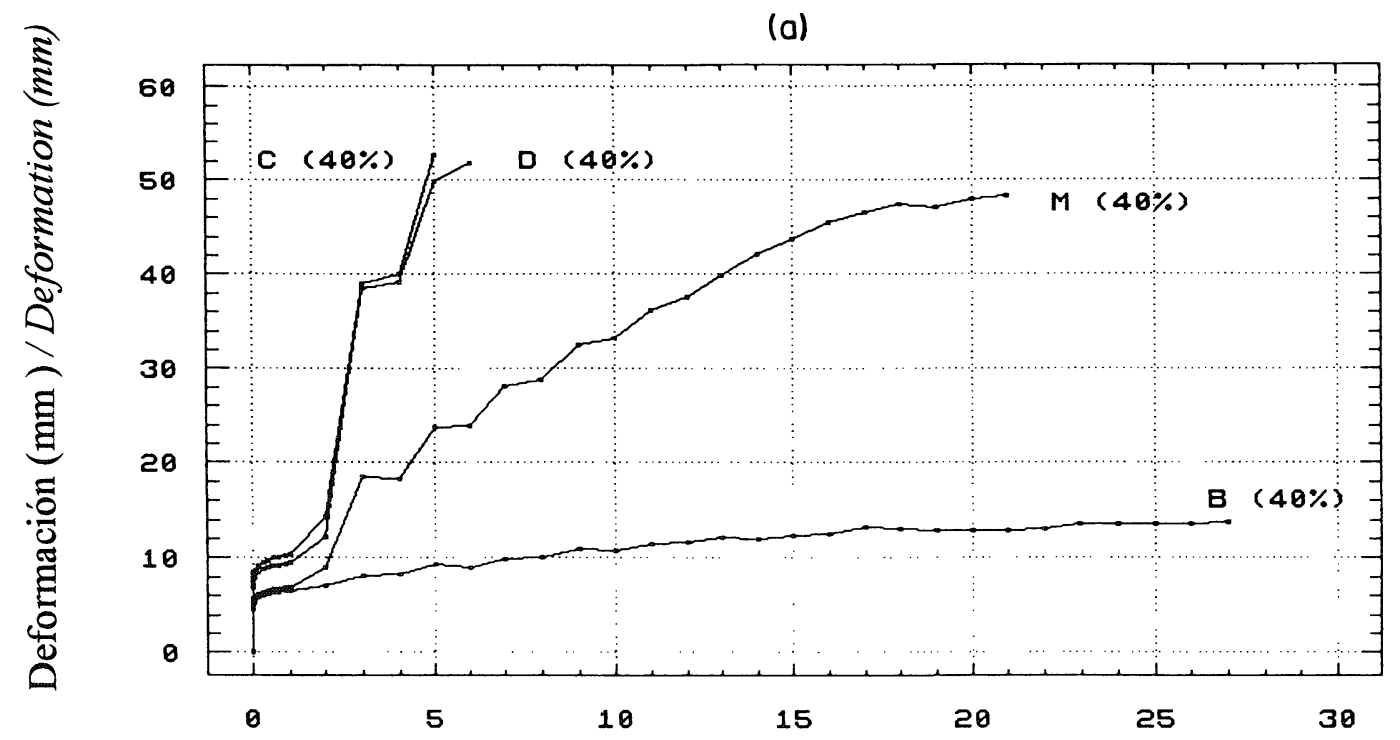

Tiempo (semanas) / Time (weeks)

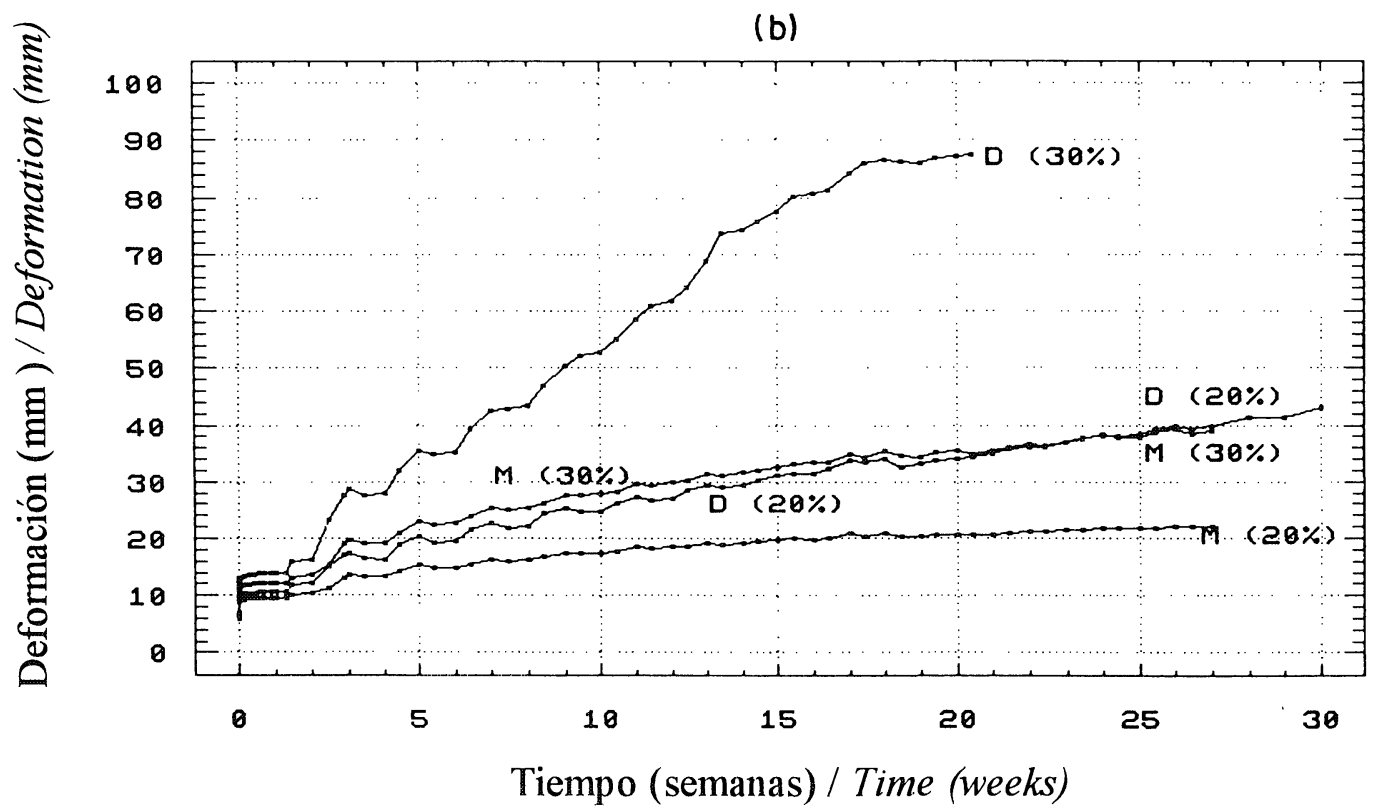

Fig. 1.- - ivolución de la flecha absoluta: (a) tableros B. C. l) y M al 40\% de tensión: (b) tableros I) y M para los niveles de tensión del 20 y $30 \%$

Fig. I.- Evolution of absolute deformation: (a) boards B, (', I) and $M$ at $40 \%$ stress; (b9 boards I) and M at stress levels of 20 and $30 \%$. 
radicalmente el material, al disminuir de forma clara el valor de la fluencia relativa. Se observa, asimismo, que el simple recubrimiento de los cantos (tablero C) no modifica significativamente el comportamiento del tablero base (D).

El análisis de la humedad de equilibrio higroscópico de las probetas de ensayo (TABLA 5) permite observar que hay muy poca diferencia entre los tableros $\mathrm{D}$ y $\mathrm{C}$, que el tablero $M$ presenta valores similares a los vistos para los tableros D y C y que el tablero B presenta un comportamiento acusadamente diferente, lo cual confirma que el recubrimiento simultáneo de caras y cantos modifica radicalmente el comportamiento del tablero. radically change the behaviour of the raw material (board D) as the relative creep is clearly reduced. Simple edge banding material (board C) shows no significant change in the behaviour as regards the raw material (D).

The analysis of the equilibrium moisture content (e.m.c.) of test samples (TABLE 5), shows that there is very little difference between boards $D$ and $C$ and also between boards $M, D$ and $C$, whereas board $B$ exhibits a strikingly different result, therefore confirming that the process of overlaying edges and surfaces radically changes the behaviour of the board.

TABLA 5 (TABLE 5)

Variación del contenido de humedad de las probetas de ensayo (Valores extremos en \%) (Variation of the moisture content of samples)

\begin{tabular}{|c|c|c|}
\hline \multirow{2}{*}{$\begin{array}{c}\text { TABLERO } \\
\text { (BOARD) }\end{array}$} & \multicolumn{2}{|c|}{ CONDICIÓN (HUMIDITY LEVEL) } \\
\cline { 2 - 3 } & $20^{\circ} \mathrm{C} / 90 \% \mathrm{hr}(r h)$ & $20^{\circ} \mathrm{C} / 30 \% \mathrm{hr}(r h)$ \\
\hline D & 9,9 & 6,3 \\
\hline C & 9,7 & 6,1 \\
\hline M & 9,6 & 6,3 \\
\hline B & 8,4 & 7,4 \\
\hline
\end{tabular}

De lo anterior se pone en evidencia que el recubrimiento melamínico de las caras influye, de forma significativa, en el comportamiento reológico del tablero base por modificación de las características mecánicas de este material, pero no por modificación del comportamiento a la sorción/desorción, ya que los contenidos de humedad de los tableros D y M son similares. Por otra parte, es evidente la influencia que en el fenómeno reológico tiene el contenido de humedad del tablero y su variación, ya que tablero B, con contenidos de humedad muy inferiores y estables, presenta un comportamiento reológico muy superior al del resto de tableros (C, D y M).

Un análisis del proceso de alternancia de flechas (Fig. 2), inducido por los cambios de humedad relativa del medio, evidencia un comportamiento del tablero MDF ligeramente diferente que el de tablero de partículas. Estas diferencias pueden resumirse como sigue:

-El comienzo de la alternancia de flechas en MDF es muy anterior ( $2^{a}$ semana) que en tablero de partículas $\left(7^{a}-8^{a}\right.$ semana).
The flexure creep behaviour of MDF panels in a cyclic humidity environment can be reduced by surface coating with melamin resin-impregnated paper. C'oating of surfaces seems to affect creep behaviour by modifying the mechanical characteristics of the raw panel used as substrate but not its sorption behaviour as the moisture content of boards $D$ and $M$ are similar. On the other hand. the influence that the moisture content of the board has on its creep behaviour and its variation become apparent as board $B$, whose moisture is considerably lower and stable, reflects a rheological behaviour which is significantly better than that of the other tested boards (C,D and M).

A comparative analysis of the process of alternation of deformation (Fig. 2) during the cycles of sorption/ desorption in both MDF and particleboards, reflects a slightly different behaviour in MDF panels compared with particleboards. These differences can be summarized as follows:

-Alternating deformation phenomenon appears much sooner in MDF boards (2nd week) than in particleboards (7th-8th week). 


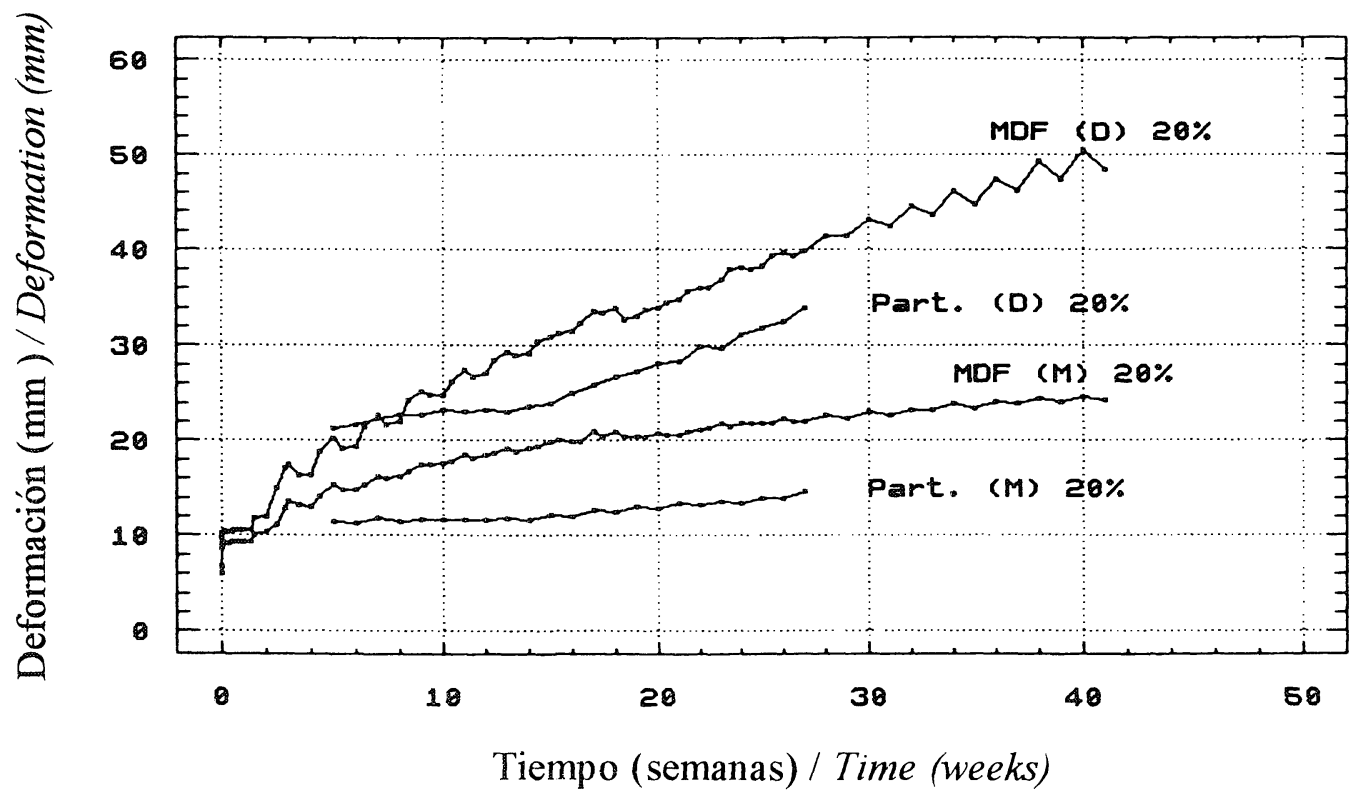

Fig. 2.- Comparación de la deformación absoluta en tableros de partículas y. MI) - para un nivel de tensión del $20 \%$ Fig. 2.- Comparison of the absolute deformation of particle and MI) boards, at a stress level of $20 \%$.

-En las primeras semanas $\left(2^{\mathrm{a}}\right.$ a $\left.18^{\mathrm{a}}\right)$ el fenómeno de alternancia de flechas es similar al observado en tablero de partículas.

A partir de la semana $31^{\mathrm{a}}$ se observa una inversión del fenómeno de alternancia, apareciendo una recuperación de la deformación tras cada ciclo húmedo. Se observa, también, una intensificación del proceso de alternancia (diferencia entre flecha máxima y mínima en cada ciclo) conforme avanza el experimento.

Entre ambas fases (semanas $18^{\mathrm{a}}$ a $31^{\mathrm{a}}$, para un nivel de tensión del $20 \%$ ) se produce un comportamiento casi lineal en el que el proceso de alternancia de flecha es muy reducido.

Tras cada ciclo completo (sorción/desorción) el valor de la deformación absoluta aumenta en todos los casos.

La aparición del fenómeno de recuperación de flecha en la fase húmeda se retrasa con la aplicación de los recubrimientos de cara (tablero $\mathrm{M}$ ) y completos (tablero B).

No se han encontrado referencias bibliográficas de este fenómeno en otros autores $\mathrm{y}$, de momento, no tenemos explicación al fenómeno observado, si bien podemos avanzar la hipotesis de que la inversión del proceso de alternancia detecta el comienzo de una fase de rotura incontrolada del material.

El análisis de los datos correspondientes a los mayores niveles de tensión (40\%), en los que aparece
-In the first weeks (2nd to 18th week) alternating deformation phenomenon is similar to that observed in particleboards.

from the 31 st week onwards, a reversal in the alternating deformation process was witnessed, with a recuperation in deformation following each humid cycle. The alternation process is also intensified (the difference between the maximum and minimum deformation levels of each cycle) as the experiment proceeded.

Between both phases (weeks 18 to 31, at a stress level of $20 \%$, the behaviour observed was almost lineal, in which the alternating deformation was extremely low.

following each complete cycle (sorption desorption). the level of absolute deformation increased in all cases.

The occurrence of deformation recuperation in the humid part of the cycle was delayed if the surfaces (board .1/). or the whole hoard (board B), were overlaid.

II e have been unable to find any hibliographical reference to this type of phenomenon, and for the time being we have no explanation for this result, although we suggest that the reversal of the alternating process reflects the beginning of a uncontrolled failure phase.

The analysis of the information corresponding to the highest stress level $(40 \%)$, in which the tertiary phase, or 
claramente la fase terciaria, o de rotura incontrolada del material, permite observar que el modelo general propuesto por Laufenberg (23) es muy apropiado para la explicación general del proceso. La cierta complejidad observada en el comportamiento reológico de los tableros MDF se traduce en una fase secundaria no lineal al estar compuesta, a su vez, por varios tramos asumibles como lineales.

De los datos de la TABLA 4 y de la Figura 2, se puede deducir que, a igualdad de nivel de tensión aplicada, la deformación del tablero MDF es siempre superior que la del tablero de partículas, si bien el comportamiento es justamente el contrario que cuando el análisis se efectúa teniendo sólo en cuenta la carga $(\mathrm{kg})$ aplicada. De aquí se deduce que cuando la comparación se hace considerando el mismo nivel tensional, los tableros MDF presentan comparativamente un peor comportamiento que los de partículas, lo que no ocurriría si se hiciera uso del mismo nivel de carga absoluta aplicada ( $\mathrm{kg}$ ). Este fenómeno es evidente tanto si se hace uso de la flecha absoluta como de la fluencia relativa (valores entre paréntesis en la TABLA 4).

\subsection{Modelización de la curva deformación-tiempo}

Sobre los datos de deformación absoluta hasta la semana 42 (Fig. 2), en mm, se intentó, infructuosamente, el ajuste de un modelo matemático del tipo $1 /$ flecha $=a+b \cdot$ tiempo, empleado ya anteriormente con tableros de partículas (21).

Después de varios intentos con diversos modelos matemáticos, el que aportó un grado de ajuste más satisfactorio, resultó ser el siguiente: $Y=A+B \cdot t+C \cdot t^{2}$

donde $\mathrm{Y}$, representa la flecha absoluta, en $\mathrm{mm}$, y $\mathrm{t}$, el tiempo, en horas.

La TABLA 6 recoge los valores de los parámetros de dicha función y los coeficientes de determinación del modelo matemático ajustado a los datos de evolución de la flecha con el tiempo para los tableros D y M y un nivel de solicitación del $20 \%$. uncontrolled and massive failure, is clearly present, allows us to conclude that the general model proposed by Laufenberg (23) is appropiate for the explanation of the creep-rupture phenomena. The complexity of the rheological behaviour of the MDF boards is evident in its secondary and non-lineal phase, as it is composed of a series of steps that individually can be considered to be lineal, being the shape of the total curve convex.

From the data in TABLE 4 and Figure 2, it can be deduced that, for the same stress level, the deformation in $M D F$ boards is always higher than in particleboards, although the result is just the opposite when the comparison is made taking into account only the same level of load $(\mathrm{kg}$ ) applied. Therefore, it can be deduced that when the comparision is made using the same stress levels, MDF boards reflect a behaviour that is comparatively worse than that reflected by particleboards, which does not happen if the same absolute load (kg) is considered. This phenomenon happens regardless of if absolute or relative deformation is used.

\subsection{Modelization of the time-deformation curve}

In the data of absolute deformation up to week 42 (Fig. 2), in $\mathrm{mm}$, it was impossible to fit the empirical model, lideformation $a \cdot b \cdot$ time, previously used on particleboards (21).

The mathematical model, that fitted the data much more closely was the following: $Y \cdot A: B \cdot t \cdot C \cdot t^{2}$

where Y, represents absolute deformation, in $\mathrm{mm}$, and $t$, represents time, in hours:

TABIE 6 collects the estimated parameters A, B and $($, and the coefficients of determination of the mathematical model fitted to time-deflection data for boards I) and $M$ at a stress level of $20 \%$

TABI A $6($ TABLE 6)

Resultados del ajuste del modelo $\mathrm{Y}=\mathrm{A}+\mathrm{B} \cdot \mathrm{t}+\mathrm{C} \cdot \mathrm{t}^{2}$

(Estimated parameters for the $Y=A+B \cdot t+C \cdot t^{2}$ model)

\begin{tabular}{|c|c|c|c|c|}
\hline \multirow{2}{*}{ BOARD } & \multicolumn{4}{|c|}{ PARÁMETROS ESTIMADOS (ESTIMATED PARAMETERS) } \\
\cline { 2 - 5 } & $\mathrm{A}$ & $\mathrm{B}$ & $\mathrm{C}$ & $\mathrm{R}^{\prime}$ \\
\hline M & $10.376 \pm 0,24$ & $1.547 \pm 0,034$ & $-0,015 \pm 0,0009$ & 99 \\
\hline D & $4.654 \pm 0,53$ & $4.77 \pm 0,165$ & $-0,039 \pm 0,0089$ & 99 \\
\hline
\end{tabular}


Un análisis comparativo de los datos obtenidos con el tablero MDF y con el de partículas, permite observar que mientras el modelo propuesto para tableros de partículas tenía una marcada concavidad (debido probablemente a la temprana aparición de la fase terciaria o de rotura incontrolada del material), el propuesto para tableros MDF presenta convexidad. Este diferente comportamiento de la deformación se explica por la mayor sensibilidad del tablero de partículas ante las condiciones de humedad relativa alternantes.

Mediante un experimento en paralelo (24) se pudo comprobar que el tablero de partículas presenta una velocidad de ganancia y pérdida de humedad del medio muy superior a la del tablero MDF, lo que hace que las condiciones de humedad relativa alternantes de corta duración le sean mucho más agresivas. $\mathrm{Si}$, por el contrario, se consideran condiciones húmedas $\left(20^{\circ} \mathrm{C} / 90 \% \mathrm{hr}\right)$ de larga duración, la ganancia total de humedad y la consiguiente degradación físico-mecánica del tablero es muy superior en tableros MDF que en tableros de partículas

Lo anterior justifica que las condiciones más duras a las que puede verse sometido un tablero MDF son las que implican una humedad relativa alta y mantenida en el tiempo. Por tanto, si se desease realizar el ensayo reológico de estos tableros en las condiciones más desfavorables, debería hacerse con una humedad relativa del $90 \%$

El hecho de que las condiciones alternantes del medio no sean tan agresivas para el tablero MDF como para el tablero de partículas puede explicar su diferente comportamiento reológico y la imposibilidad del ajuste del modelo lineal propuesto en anteriores estudios (21) para tableros de partículas.

\section{CONCLUSIONES}

1.- Al igual que con tablero de partículas, el nivel de solicitación aplicado influye decisivamente en el comportamiento reológico de los tableros MDF, acortando su vida en servicio y aumentando la velocidad de la deformación al incrementar el nivel de tensión.

2. - La propensión hacia la fluencia, en las condiciones de estudio, es más marcada en tableros MDF que en tableros de partículas cuando la comparación se efectúa considerando el mismo nivel de tensión. Cuando la comparación se efectúa considerando la misma carga absoluta aplicada ( $\mathrm{kg}$ ) el resultado es, justamente, el contrario.
A comparative analysis between the results from $M D F$ boards and particleboards, reflects that while the model used for particleboards resulted in a marked degree of concavity (probably due to the early appearance of the tertiary phase or massive failure of the material), the model used for MDF boards presented convexity. This different deformation behaviour can be explained by the greater sensitivity of particleboards to the alternating relative humidity conditions.

Using a parallel experiment (24), whose results will be published at a later date, it was seen that particleboards gain and lose humidity at a rate much higher than that of $M D F$ boards, which therefore means that particleboards are much more vulnerable to short term alternating relative humidity conditions. If, on the other hand,long term humidity $\left(20^{\circ} \mathrm{C} / 90 \% \mathrm{rh}\right)$ conditions are considered, the total humidity gain and the resulting physicomechanical degradation of the board is far greater in MIIF hoards than in particleboards.

From the above mentioned results, it can be concluded that the conditions that most affect MDF boards are those of high relative humidity maintained over a long period of time. Therefore, if the most unfavourable conditions are sought to carry out a creep test on MIIF. it should be considered a constant and high. $90 \%$. relative humidity.

The fact that alternating environment conditions are not so detrimental for MDF boards as for particleboards can explain their different rheological behaviour and the impossibility of fitting the lineal model suggested in previous studies (2l) on particleboards.

\section{CONCLUSIONS}

1.- As in particleboards, in MIPF panels, increasing the level of stressing resulted in lower time to failure and in higher rates of def.ormation.

\section{2. - Propensity to creep, under the conditions used, is} greater in MII) boards than in particleboards when the comparison is made with the same degree of stress. When the comparison is made at the same level of load (kg), the result is the exactly the opposite. 
3.- La propensión hacia la fluencia, medida ésta tanto en términos de flecha absoluta como de fluencia relativa, queda significativamente reducida mediante la aplicación de revestimientos superficiales melamínicos de tipo tradicional. El recubrimiento es también muy eficaz en el amortiguamiento del fenómeno de alternancia de flecha que se produce como consecuencia de los ciclos de sorción/desorción inducidos en el tablero por la ejecución de los ciclos de humedad relativa $\left(20^{\circ} \mathrm{C} / 30 \% \mathrm{hr}-20^{\circ} \mathrm{C} / 90 \% \mathrm{hr}\right.$ ).

4.- El recubrimiento con melamina de los cantos (tablero C) no modifica el comportamiento reológico de los tableros base (D), salvo cuando se combina con el recubrimiento de las caras (tablero $\mathrm{B}$ ).

5.-El modelo lineal del tipo $1 / \mathrm{f}=\mathrm{a}+\mathrm{b} \cdot \mathrm{t}$, aplicado con éxito en la predicción de la flecha en los tableros de partículas, desnudos y revestidos, se ha mostrado inadecuado con los tableros MDF. Para estos últimos ha quedado demostrada la aplicabilidad del modelo de tipo polinómico:
3.- Propensity to creep, measured both in terms of absolute deformation and relative creep, is significantly reduced if both surfaces are overlaid with melamin resin-impregnated $80 \mathrm{~g} / \mathrm{m}^{2}$ paper. Surface coating is also extremely effective in counteracting the phenomenon of alternating deformation caused by the sorption/ desorption cycle in boards as a result of relative humidity cycles $\left(20^{\circ} \mathrm{C} / 30 \% \mathrm{rh}-20^{\circ} \mathrm{C} / 90 \% \mathrm{rh}\right)$.

4.- Edge sealing by means of commercial flexible and adhesive-bonded (solvent-based) polyester edge banding material (board (C), does not affect the rheological behaviour of boards, except if the surfaces are also overlaid (board B).

5. - The lineal model, 1/deformation $=a+b \cdot t$, successfully employed in the prediction of deformation in particleboards. both overlaid and raw, cannot be used with MDF boards. For these boards, the polinomic model:
6.- El fenómeno de la alternancia de la flecha ante los ciclos de sorción/desorción sufridos por el tablero MDF, aunque más temprano, sigue el mismo patrón que en tableros de partículas (flecha aumentando en la fase de sorción) hasta, como media, la semana 18 , momento a partir del cual se invierte ligeramente, siguiendo un patrón muy similar al de la madera maciza. Se aventura la posibilidad de que este fenómeno sea debido a la inminencia de un cambio de fase hacia una fase final o de rotura incontrolada del material.

7.- De los datos existentes parece deducirse que para los tableros MDF ensayados, las condiciones fijas de $20{ }^{\circ} \mathrm{C} / 90 \%$ son más agresivas que las alternantes de $20^{\circ} \mathrm{C} / 30 \%-20^{\circ} \mathrm{C} / 90 \%$.

8.- No se ven razones por las cuales los tableros MDF no puedan ser empleados en las mismas aplicaciones constructivas en la clase de servicio 2 en las que actualmente son empleados con éxito los tableros de partículas. Se recomienda, no obstante, por el riesgo de presencia de agua líquida, que cuando estos tableros vayan a ser colocados como base de cubiertas lo sean dotados con un revestimiento melamínico superficial, prestando gran atención a la colocación de aislantes térmicos y de barreras de vapor en la cara caliente de los tableros. El empleo de sistemas de sellado superficial (especialmente mediante el uso de bandas de $10-15 \mathrm{~cm}$ de espesor) de la juntas entre tableros está fuertemente recomendado para evitar la entrada de agua líquida por los cantos.
6.- The alternating of deformation during the sorption/desorption cycles, takes place earlier in $M D F$ boards than in particleboards, although following the same pattern (deformation increases during the sorption phase) until, on average, week 18 , from this moment onwards the pattern is somewhat reversed, following one similar to that of solid wood. It is possible that this phenomenon is caused by the imminence of the beginning of the change to the final phase (tertiary phase, according to Laufenberg), or the uncontrolled (massive) failure of the material.

7.- From the existing data, steady conditions of $20^{\circ} \mathrm{C} / 90 \%$ rh seem to be more destructive for MDF boards (at least for the ones tested in this experiment) than cyclic conditions of $20^{\circ} \mathrm{C} / 30 \%-20^{\circ} \mathrm{C} / 90 \%$

8. - Are not seen reasons by those wich the MDF panels could not be used in the same constructive applications in the class of service 2 of Eurocode 5 in those wich currently they arre used with success the particleboards. It is recommended, nevertheless, due to the risk of presence of liquid water, that when the boards is planned to be used in roofs, they will be protected with melamin-surface coatings, paying a great attention to a proper siatuation of the insulation and of the vapour barrier, always in the inside face. Joints sealings are also strongly recommended to avoid liqquid water penetration by the edges. 
9.- Como conclusión final y resumen de todas las anteriores, y del trabajo mismo, puede decirse que el tablero MDF NO presenta un comportamiento peor que el de partículas, sino que aparentemente resulta peor si la comparación se efectúa considerando los mismos niveles de tensión en ambos tipos de tableros. Por contra, si la comparación se efectúa para idénticos niveles de carga aplicada $(\mathrm{kg})$, el resultado obtenido permite deducir un comportamiento significativamente mejor en el tablero MDF, al menos en condiciones de humedad relativa alternante. Puede decirse, pues, que a igualdad de espesor el tablero MDF aguanta más carga (kg) y durante más tiempo, si bien las condiciones de humedad relativa elevada y mantenida en el tiempo le afectan más negativamente, aunque no ocurre lo mismo con las condiciones alternantes. Por todo ello sólo deberán considerarse precauciones especiales (recubrimientos) en los ambientes húmedos sostenidos (por ejemplo, al borde del mar, en cubiertas de piscinas, etc.). Finalmente, debe decirse que el recubrimiento melamínico, al igual que ocurría con el tablero de partículas, protege muy eficazmente al tablero, alargando su vida y haciendo que se deforme notablemente menos.
9.- As final conclusion and summary of all the previous, and of the entire work, it can be said that the MDF panels does NOT present a worse behaviour than that of particleboards, but apparentely results worse if the comparison is carried out considering the same stress levels (\%) in both types of boards. On the contrary, if the comparison is made for the same load levels (kg), the obtained result permits to deduce a significantly better behaviour in the MDI panels. at least in conditions of alternating relative humidity. For such reasons, it can also be said that for the same thickness and in cyclic environmental conditions, the $M I F$ panels supports more load and during more time than particleboards, even though the the situations of high and constant relative humidity (90\%) seems to affect them more negatively. According to this, it is only necessary to consider special cautions (surface coatings) in constant and humid environmental conditions (for example near the sea, in pool covers. etc). Finally it must be said that the melamin coating protects very effectively the panels, lengthening its life and reducing the total deformation under load.

\section{BIBLIOGRAFÍA}

(1) HOLZER, S.M.; LOFERSKI, J.R.; DILLARD, D.A.: (1989). A review of creep in wood: concepts relevant to develop log-term behaviour predictions for wood structures. Wood and Fiber Science 21(4): 376-392.

(2) DINWOODIE, J.M.: BONFIELD, P.W.: (1995). Recent european research on the rheological behaviour of wood based panels. In Proceedings of the COST 508 Workshop March 1995.

(3) DINWOODIE, J.M.; HIGGINS, J.A.; PAXTON, B.H. ; ROBSON, D.J.: ( 1990). Creep research on particleboard. Holz als Rohund Werstoff 48: 5-10.

(4) BOEHME, C.: (1992). Creep behaviour of UF bonded MDF. Holz als Roh-und werkstoff. 50: 158-162.

(5) FERNÁNDEZ-GOLFÍN, J.I.; DÍEZ BARRA, M.R.: (1992). Langzeitverhalten von Spanplatten unter variablen Feuchtebedingungen. Untersuchung des Einflusses von Beschichtungen und Klebstoffen. Holzforschung und Holzverwertung 44(6): $106-110$.

(6) BACH, L.; ZHAO, N.W.; CHENG, J.J.R.: (1993). Surface coating can reduce creep of oriented strandboard. Forest Prod. Journal 43(6):43-44.

(7) BRYAN, E.L.: (1960). Bending strength of particleboard under long-term load. For. Prod J. 10(4):200-205.

(8) KUFNER, M.: (1970). Das kriechen von holzspanplatten bei langzeitiger biege beanspruchung. Holz Als Roh-und Werks. 28:429-446.

(9) GRESSEL, P.: (1972). The effect of time, climate, and loading on the bending behaviour of wood based materials. Part I: previous investigations, testing plan, research methods. Holz Als Roh-und Werks. 30(7):259-266. Part II: test results in dependency on the creep parameters. Holz Als Roh-und Werks. 30(9):347-355. Part III: discussion of results. Holz Als Roh-und Werks. $30(12): 479-488$.

(10) GRESSEL, P.: (1984). Prediction of long-term deformation behaviour from short-term creep experiments. Holz Als Roh-und Werks. 42:293-301.

(11) ARMSTRONG, L.D.; GROSSMAN, P.U.A.: (1972). The behaviour of particleboard and hardboard beams during moisture cycling. Wood Sci. Technol. 6:128-137. 
(12) HALLIGAN, A.F.; SCHNIEWIND, A.P.: (1972). Effect of moisture and creep properties of particleboard. For. Prod. J. 22(4):41-48.

(13) HAYGREEN, J.H.; HALL, K.; YANG, N.; SAWICKI, R.: (1975). Studies on flexural creep behaviour in particleboard under changing humidity conditions. Wood Fiber Sci. 7(2):74-90.

(14) LEHMANN, W.F.: (1978). Cyclic moisture condictions and their effect on strength and stability of structural flakeboards. Forest Prod. Journal 28(6): 23-31.

(15) LEHMANN, W.F.; RAMAKER, T.J.; HEFTY,F.V.: (1975). Creep characteristics of structural panels. Proceedings 9th Washington State Univ. Symp. on particleboard. pp:151-172.

(16) MCNATT, J.D.; HUNT, M.O.: (1982). Creep of thick structural flakeboards in constant and cyclic humidity. For. Prod J. $32(5): 49-54$

(17) CHOW, P.: (1982). Bending creep behaviour of Acer saccharum marsh veneered medium density fibreboard composite. Wood Sci. Technol. 16(3):203-213.

(18) DINWOODIE, J.M.; PAXTON, B.H.; PIERCE, C.B.; ALOYSIUS, E.J.: (1985). Quantification and prediction of creep in particleboard and other wood-based sheet materials. In Proceedings of the Symposium Forest Products Research International, achievements and future, Pretoria, April 1985.

(19) DINWOODIE, J.M. et al.: (1992a). Creep in chipboard. Part 10: The effect of variable climate of the creep behaviour for a range of chipboards and one waferboard. Wood Sci. Technol. 26: 39-51.

(20) DINWOODIE, J.M. et al.: (1992b). Creep in chipboard. Part 11: The effect of cyclic changes in moisture content and temperature on the creep behaviour for a range of boards at different levels of stressing. Wood Sci. Technol. 26: 429-448.

(21) FERNÁNDEZ-GOLFÍN, J.I.; DÍEZ BARRA, M.R.: (1992). Predicción del tiempo hasta la rotura a flexión de tableros de partículas sometidos a condiciones cíclicas de humedad relativa. Materiales de Construcción 42(225):31-35.

(22) HALL, H.; HAYGREEN, J.: (1978). Flexural creep of 5/8 inch particleboard and plywood during 2 years of concentrated loading. For. Prod. J. 28(6): 19-22.

(23) LAUFENBERG, T.L.: (1988). Compositeproducts rupture under long-term loads: a technology assessment. Proceedings 22nd International particleboard/composite materials Symp. Pullman, W.A. Washington State Univ. pp:247-256.

(24) FERNÁNDEZ-GOLFÍN, J.I.; DÍEZ BARRA, M.R.: (1997). Efecto de las condiciones ambientales sobre las propiedades físico-mecánicas de tableros MDF. Revista de Investigación Agraria (en prensa). 